DE DE GRUYTER

OPEN

DOI: $10.1515 /$ aa-2015-0009

\title{
Documentary film as historical narrative
}

\section{Marek Urban}

Marek Urban is a doctoral candidate at the Institute of Theatre and Film Research of the Slovak Academy of Sciences in Bratislava and graduated in documentary filmmaking from the Academy of Performing Arts in Bratislava, and film studies from Masaryk University, Brno, Czech Republic. At present, his primary interest is anthropological research on Slovak cinema.

\begin{abstract}
The submitted study describes the documentary film as a historical narrative that carries within it problems documented by historians such as Paul Veyne and Hayden White. It argues on behalf of the thesis that a documentary film in itself does not classify historical clues according to historical truth but according to a selected purpose (e.g. despite aesthetic conventions or in the case of a narrative film - according to the story). The study refutes the argument of Noël Carroll, who deals with the popularizing documentary film - specifically, connecting scientific "truth" with the tropological character of a documentary film narrative can create at best an approximate picture of a historical event.
\end{abstract}

In the submitted study we want to argue on behalf of the premise that any documentary film is a priori a historical narrative - a story. This means that if the film speaks about any subject it must essentially share the problematic quality emerging from its historiographical essence. This could be summarized approximately in this way: "Since the end of the 1960s we have had no doubt that 'historical fact' is first of all a construct, an interpretation of data, an artificial operation, which 'treats documents', namely such that it actually shapes them" (Ferenčuhová, 2009, p. 32-33). Modern historiography has a markedly reserved relationship towards historical "truth", designating it as at best approximate, or partial truth (Veyne, 2010, p. 61). Understanding the relationship between documentary film and historiography can open up completely new possibilities of reception and also in the creation of documentary films. We shall begin our argument with a description of a film recording.

\section{A film recording as a historical clue}

We consider a film recording as any unedited film material that originated by the recording of reality in front of a camera (profilmic reality) without regard to purpose. In this 
phase we are not interested whether the recording originates from a security camera or serves as the preservation of memories from a summer holiday.

We want to ask the questions: does the possibility exist of preserving a historical event on film? Is it possible to objectively record an event on an unedited film recording? First of all, we want to focus on an utterly common objection against documentary film relating to the selectivity of film equipment: a film recording is in its own essence limited by different internal and external parameters. Where do I place the camera? Do I use a wide-angle lens? Will I have only this character in the shot or the whole crowd? Will it be a small detail or a large whole? Will I shoot from a hand-held or use a tripod? Will the film be black-and-white or colour?

The consequences are not only aesthetic. Aside from the fact that the selectivity of the film equipment literally filters the amount of information that is depicted from living reality, each parameter also influences our emotional and rational understanding and experiencing of what is seen. An under-view shot can be an equally significant element as, let's say, a commentary; it's enough to answer the question of why promotional films made by political parties, similar to the speeches of the otherwise short Adolf Hitler, are as a matter of principle taken from below (e.g. in Triumph of the Will Leni Riefenstahl organizes the mise-en-scène so that events appear as more monumental, more noble than in reality).

Noël Carroll argues that selectivity doesn't mean an automatic loss of objectivity, because not only is film selective but so are practically all areas of research, from physics to history up through journalism: "So long as we do not label physics and history as unobjective only because they are selective, then no reason exists why we should a priori doubt the trustworthiness of a documentary film only because it is selective. Without selectivity we cannot have chemistry or even economics" (Carroll, 1996, p. 283).

Carroll's defence has several weak points. It ignores, for example, the different methodological possibilities of the social and natural sciences. While in physics it is possible to study closed systems with a known number of variables that can be changed by intervention, the social sciences do not have such a possibility available to them. At the same time an important difference lies in the fact that the natural sciences attempt to describe a phenomenon itself, which represents for the social sciences a principle problem. For example, the impossibility of capturing a historical event, that is any event per se, in its totality is the foundation of an argument that develops from historiography and which we will devote ourselves to later. However, it is also not necessary to overestimate the objectivity of the natural sciences: as Paul Veyne writes (2010, p. 61), while historical truth is partial, scientific 
truth is temporary. Newton's physics after all were valid as objective truth for two centuries, until it was found that this truth is not sufficient.

From the abovementioned, it seems that the possibility of capturing an event in its entirety on a film recording is minimal. Therefore, let's look at the consequences of the selectivity of film equipment in a hypothetical case: we discover an hour-long unedited amateur recording of a preschool gathering. We will follow unknown children as they put on a performance of the fairy tale Sol' nad zlato (Salt over Gold). If we direct our attention to the work of the camera operator, we notice that he or she focuses on one child more than on the others - parts of the zooming in are clearly on this child, even when nothing is being said. Otherwise the recording is happening in the larger whole. When the presentation is over, the audience applauds and the children take a bow. The recording ends.

We do not find out anything about the relationship between the camera operator and the child who was shown more often than the others in the footage. We do not find out anything about how the audience experienced the performance and how the children experienced it. We don't know whether parents or grandparents are sitting in the audience; we don't know whether some parents are divorced, and we don't even know how they behave towards their children after the presentation. Do they praise them, although it wasn't that good? Or do they chide them about the need to try harder? We don't know why individual children play the roles that they play. We don't know the motivation of the person who filmed the performance. We don't know the year the performance took place; we don't know the location or even the time; we don't know any names.

And yet, we can deduce the utterly exact conclusion that this gathering did at some point take place. All other conclusions that we could draw about this gathering are mere speculation based on our own experience. We can, for example, speculate that the camera operator and the girl who is shown often in the recording are related. Father and daughter? But what if the motivation is something improbable? We note that the selectivity of the film equipment conceals a huge amount of information from us, which under normal circumstances we could assign to the event. We are lacking a context and knowledge about motivations, without which we can only make mistakes in our assessment. Therefore, we come to the mechanism that generates a documentary film's context and motivation.

\section{Connecting clues and constructing events}

We have thus far only devoted ourselves to a simple, unedited record of reality - to a single clue - and we have studied the possibility that this clue reveals an event in its entirety. 
This we questioned by characterizing the film equipment as selective. But what happens if we have more clues?

[T] hat which historians call events is in no case captured directly and fully, but always only incompletely and indirectly, through documents or testimonials, that is through approximations [emphasis by Paul Veyne], clues (Veyne, 2010, p. 12).

Paul Veyne is in principle sceptical: he is presented with several clues and even these are not enough for him to consider an event as complete. We will try to look into his statement and do so such that we will add a second clue to our footage of the gathering: a recording of the recollection of one of the child actors.

The gathering took place in 1996; I must have been just over six years old. But I remember it very well. We practiced the fairy tale Salt over Gold and I very much wanted to play the prince. I also liked the classmate who was to play the princess and at the end of the play the prince danced with the princess. She was a little blonde girl (what girl isn't little when she is six), and I wanted her, and my classmate and every one of us asked her every day to marry us. Obviously, they would find no one better than I for the role of the prince, but in the end my classmate got the role, which I felt to be a great injustice. I was the cook. So then I boycotted the entire gathering a little bit; the sight of the prince and princess disrupted my concentration. I didn't do completely what I was supposed to and I spoke too loudly and I waved the wooden spoon too rapidly.

The explanation which we have just partially provided clarifies the record of the gathering and puts it into the context of the experience of one small boy. If we want, we can, for example, compare his statement on "boycotting" with the film recording and determine that in this recollection for the purpose of telling it, he takes on a little bit the role of the hero. On the other hand, with respect to the fact that he doesn't always figure in the recording and if he does, then only in the larger whole, we cannot completely disregard his statement.

We notice that we didn't learn anything about how the classmates perceived the event; we don't even know why the teacher decided as she did. Why would she leave him to play the cook and not the prince? We don't have much to say about the school gathering itself; we are able, however, to speak about the subjective experiencing of the school gathering of one boy, which we are able to supplement with a selective recording on VHS. We thus have two clues which should allow us to construct in our minds the image of an event: a preschool gathering.

Even if I were a contemporary and witness of the battle of Waterloo, and if I were a key participant and I was Napoleon himself, I would see what historians call the event Waterloo only from one perspective; [...] my own interpretation of these events would be appreciably different than the interpretation of my friends, of my confidant, my court 
historian or my psychoanalyst, who could have their own version of my decision and guess better than I what I actually wanted (Veyne, 2010, p. 13).

Let's try to ask a question: do you think that your idea of the event of a preschool gathering corresponds to reality? How many different views of the event would we need in order to declare our knowledge of the event as objective? The substantiation of the teacher? The feelings of the children? Perceptions of the parents? But their interpretations would perhaps be too subjective. What about the knowledge of a theatre critic? A paediatrician? A child psychologist?

Anyone can find an amateur film recording in the attic and only futilely try to assign meaning to it.

In its essence history is known through documents. However, such historical narratives are located outside of all documents, because none of them can be events; it isn't a documentary photomontage and it doesn't enable the seeing of the past directly 'as if you were there'; taking the useful differentiation of Gerard Genetto, we can say that it is about diegesis, not about mimesis [emphasis by Paul Veyne] (Ibid.).

We know history through documents, and for the purpose of this work we have added a second clue: the recording of a recollection. The first step a person takes on finding an old film in the attic and wanting to understand its meaning would be to speak with their grandmother. Or they would look over photographs in order to decode the main actors in the film. They would search for clues in order to be able to imagine the event depicted in the film.

We notice that it is specifically the viewer that constructs in their minds a picture of a historical event. We could label the process which runs in our minds when following the film as the work of a sculptor. At the beginning of the process the viewer-sculptor has only a vague idea what the film will be about. He knows perhaps the names, possibly read reviews, maybe only a short description of the event. Let's say that each viewer has at the beginning of the film an unprocessed piece of stone. With each clue, with each shot that he sees in the film new indications and new threads are found: the viewer hews this stone piece by piece until he achieves the final form of the sculpture. This sculpture is then the idea that the viewer acquired while watching the film. The watching of a film (Bordwell 1985) is essentially the guided creation of a hypothesis about what is happening in the film. In this way an image of a historical event arises in the mind, and this image should be in the case of a documentary film faithful to reality. 
Let us recall, however, how Bill Nichols (2011) warns against uncritical faith in the truthfulness of the opinion that a film submits to us, only on the basis of its index character. A film recording appears to us as if it depicts an event itself, which, however, cannot be true because of selectivity: "A documentary film does not only document events but also expresses a specific perspective or opinion about them. Its viewpoint or opinion merely connects to many others" (Nichols, 2011, p. 141-142). Let any number of clues be contained in the film itself; each clue would bring only a partial image of the event. No final number of clues exists, however, by whose sum we can obtain the event in and of itself.

Let us now analyse two problems which appear with our statements. We are devoting ourselves to the task of scientific truth in a documentary film and we posit the question: in what way can the clues of a historical event itself determine the image that we acquire about the event?

\section{Reconstruction of a historical event and its problems: the popular scientific film}

A documentary film originates from many clues. Every film recording is just such a historical clue. This comes from a film recording that, however, a priori gives a selective image of reality. We cannot obtain the event itself from historical clues, just as we cannot obtain a person from the footprints on a beach. We know that some person was there and on the basis of his/her footprints we can deduce perhaps what the person looked like; we can, for example, calculate his/her approximate height. We can ask someone on a lounge chair whether or not they saw this person and we can obtain perhaps a possible description of how the person looked. In other words: we can approximately imagine this person, similarly as how from historical clues we can imagine a historical event. We don't obtain the event itself, but we obtain its approximate image in our mind.

We have said that the idea of an event which we obtain from clues can furthermore be an approximate image of the event itself. Noël Carroll, against a similar statement, gives examples of different information and popular documentary films, such as City of Coral. He argues that film theorists by convention devote themselves to documentaries which we could call artful (for example, The Thin Blue Line) and ignore films which present scientific knowledge. He writes that it is nevertheless true when "we are told that pelican chicks grow down within a month after birth and that coral is part animal and part vegetable and leaves mineral deposits" (Carroll, 1996, p. 295). 
We omit now for a moment the fact that scientific truth is provisional truth, and we consider the statement on the growth of the pelican young and corals as objective and scientifically demonstrable. We ask the question: what does the film show us when we know this information? What kind of guide does the commentary give us and what kind of guide does the image thrust upon us? We see the pelican young and the commentator tells us about these young birds: "After a month they begin to discover their own wings." We see a young pelican waggle his little featherless wings. The narrator continues: "And after another month they will fly like their parents." A jump-edit follows along the axis of adult pelicans, which jump around the ground in their surroundings and at the same time flap their wings.

At first glance, both pieces of information appear to be complementary. Upon a closer look, however, the problem arises that we actually don't know at all what will happen with these specific pelicans in a month or two. Perhaps a storm will come and the pelicans will drown; perhaps a predator will come and eat the small pelicans; perhaps a parent of the small pelicans will break a wing and the small pelicans will die of hunger. And if they don't die, it's possible that this will not take a month, but only 28 days, or 32 days depending on how much food they get from their parents or whether or not they have siblings. In order for us to be certain that these small pelicans really begin to feel their wings within a month and begin to fly a month later, the film would have to reflect two months from the life of these pelicans. Except that even if the film reflected two months from the life of pelicans, it could only inform us about these specific pelicans: these small pelicans managed it; others don't necessarily have to. A film is always specific; a film always reconstructs only one specific historical event. The situation doesn't change even in the case that the film is supplemented by statistics: so many pelicans survive and so many pelicans die. Such statistics do not bring us specific knowledge; we don't see $60 \%$ of pelicans living and we don't see $40 \%$ of pelicans dying. Statistics don't show us the specific death which the film mediates to us: a film can always show only a specific pelican in a specific situation. And if we were to see tens of pelicans die in the film this doesn't mean that other pelicans also die in this way.

The problem is in the way the viewer deduces from the shot of a pelican and the commentary which is assigned to this footage that the depicted pelican is an archetype of all existing pelicans: this pelican thus becomes an example of the essence of the idea of "pelicanism". One specific pelican in a film becomes for the viewer representative of all pelicans and thus ignores the unique characteristics of other pelicans.

In the case of popular documentary films we are confronted with the distinctness of historical (partial) and scientific (provisional) truth, while in the case of documentary films 
which Noël Carroll describes as "artistic", we meet only with historical truth. We cannot, however, fall under the illusion that the popular films are objective only because ideas are addressed in the commentary that are momentarily demonstrable scientifically. It is specifically the connection of these two truths that compels the viewer to form untruthful conclusions - to consider a specific case as a generally applicable model.

\section{The selection of clues: the purposeful selection of selectivity}

We have said that film equipment is a priori selective. However, not only profilmic reality recorded on raw film footage functions by selection. Selection also takes place between the individual clues. By what criteria does a director include shots in a documentary film? Why use this particular clue? Why this particular footage and not some other? Why do we edit this part of the footage and not another part?

Or otherwise, let us ask the question: according to what key do we select the footage which we use in a film? Surely all footage depicts historical factuality - each of them has equal potential to preserve the historical "truth". Paul Veyne writes that "the history of an uprising can dare to be boring without losing its value" (Veyne, 2010, p. 20). Does this mean, then, that we can use all the footage that we own? Or does this mean that we actually have an obligation (towards historical truth) to use all footage in order to be able to depict a historical event in as much detail as possible? Does this mean that all documentary films must look like Andy Warhol's 321 minute-long Sleep, a detailed reconstruction of the historical event of a man's sleep?

The answer is not a simple one. Since we have shown that we cannot obtain an event itself from clues, the selection, frequency and method of using the clues depends practically only on what we want to say with the film. Warhol's Sleep is the film that it is, not because it is meant to be an aid for the scientific study of the physiology of sleep or even because sleep is such a common matter that it is worth recording in such detail. Warhol's Sleep is not interesting for what it is, but, it can be said, because of how it came about. Warhol, namely with his film, stood in sharp opposition to the Hollywood mainstream of the time, in which films predominated that were epic, exquisitely staged and filled with information, such as the 216 minute-long Lawrence of Arabia. Only in this context does Sleep acquire meaning; only in this context are we able to consider the use of five hours of "non-heroic" footage of sleep as justifiable. In other words, we can state that in a film we are working with film footage with respect to the purpose which we are watching the film. This is the purpose of the film, which justifies the use or non-use of individual clues. 
The selection of footage thus consists in whether this footage suits or doesn't suit us in order to fulfil of the purpose that we impose on the film. What is the purpose? In the case of Warhol this was a defining gesture towards the mainstream, the building of its own image. How does a narrative documentary film progress?

\section{Selection of facts is subject to the story}

A narrative film develops a story where the existence of individual events is subject to the origin of others. Without causal reasons no story would exist. The problem with causality arises when we ask the question: what is the difference between causality in a film and between causality in the real world?

The basic difference consists in intricacy: the real world is much more complicated than a film. What can be a historical event? A preschool gathering? But even a preschool gathering is formed from different events: aren't perhaps the preparation of the stage, the learning of dialogue, the arrival of parents also events? Isn't the nervous speech of the main character or the slightly excessive waving of the wooden spoon by the little cook also an event? Each historical event consists of many other historical events that mutually condition, influence or merely exist simultaneously. We are never able to determine, however, which is the foundation, the smallest event. In short, we are unable to identify what is an atomic historical fact and we are not able at all to describe the relationships between such facts.

"It is impossible to describe completely, and each description is selective; a historian never obtains a map of the field of an event; he can at best duplicate descriptions of the roads which pass through it" (Veyne, 2010, p. 53). It is impossible to describe reality in its totality, impossible to record all causes which precede any event. We have stated that in practice it applies that we must first have sources that we can draw on, and that these sources determine the image of the event that we create from them. This means that because we cannot describe reality in total, we cannot find even clues that would capture this reality; ergo we cannot even reconstruct reality. According to what, then, do we choose the facts that we will place in the film? How does the selection of historical clues take place?

Purposefully. The clues put into a film are subject to purpose. The author selects those facts that he or she considers important. "But what is important? Isn't it this about what is interesting?" (Ibid., p. 29). How do we know that some facts are interesting for us and others are not? 
Which facts are thus suitable to arouse the interest of historians? Everything depends on the incidents selected; in and of itself no fact is interesting, or uninteresting. [emphasis by Marek Urban] Is it interesting for an archaeologist to calculate how many feathers are on the wings of the Nike of Samothrace? And if this this is done, will it be proof of commendable rigorousness or of unnecessary exactitude? It is not possible to answer because a fact means nothing without all incidences; something becomes of it, since we are making a hero from it or a comparison in a dramatic history of the arts, where either the classical tendency to not create too many feathers and not fiddle with its design will be followed, or the Baroque tendency of overloading and elaborating a detail and following taste, with them barbarian art filling the field between decorative elements (Ibid., p. 51).

The selection of historical facts which appear in a film is pragmatically subject to the story which the author has selected. Hayden White states that "all histories, and those most 'synchronous' or 'structured', contain in some way a constructed story" (White, 2011, p. 22). This means that a documentary film is not only a connection of different historical clues in the interest of an exact reconstruction of historical truth. The purpose of a documentary film is a narration which should be truthful: and it is this purpose that a documentary film shares with history. Except, and this is the key question: can a narrative in its essence be truthful? Isn't every narrative in fact fictitious?

\section{Diegesis, not mimesis}

When does an event end? When does it begin? Did the preschool gathering start when the class parents arrived? Or when the children began to set up the chairs for their parents? Or when they began to rehearse for this gathering? And when did it end? When the children took a bow? When the parents left? When the teacher left the class and closed the door behind her? Did she also have to lock it? Reality does not have beginnings or even endings; stories have beginnings and endings, and according to the selected story we can also voluntarily choose the beginning and ending.

Let's return to the film City of Coral. It is paradoxical that this popular-scientific film in its exposition creates a narrative about corals as, and we quote, "the drama of coexistence", which is underscored by a sudden change of music from the playful to the dramatic. The narration begins with predators, barracudas, which are described as untiring hunters, "gray shadows on a background of the gray deep". Small fish subsequently become helpless victims wrestling for their very lives. The dramatic arc ends in the conclusion with a forgiving declaration that even barracudas have a place in the reef, because in the spirit of Darwinism they participate in the preservation of strong and healthy individuals. Nothing, however, changes the fact that the film begins and ends in this way, that it is a drama in which 
barracudas are the hunters and small fish the victims. Why doesn't the film frame the drama of the coral reefs with seagulls? Pelicans? These likewise hunt and despite this fact the film prefers to take pleasure in the gracefulness of their flight and hunt with long slow-motion footage; it speaks about their helpless young, makes a noble and majestic creature of them. Are perhaps pelicans too photogenic to become bloody predators? Why are these barracudas like this then? Only because it suits the story that the author of the film has decided to construct? The coral reef is and it is in one stroke. The entire totality of the relationship runs in a single moment. The drama is not the idea of barracudas and small fish; indeed we can state only with difficulty that they perceive their life as a drama. The drama runs in time; it has development. The fish live; they are. Here. Now. The roles and positions which we attribute to them are our roles, our constructs. Only we - people - can create the world of animals as a drama, because we know Sophocles and Aristotle; we've read Antigona and Poetics, where drama is described. It is our decision to depict the world of animals as a drama; it is our decision to show barracudas as merciless killers, small fish as the condemned in the battle for life and pelicans as beautiful and noble creatures.

The film The Earth puts polar bears in the position of victims of global warming; we follow the beautiful and majestic bears and their playful young: the idea that they must die is appalling. But let's attempt immediately after to show Werner Herzog's film Grizzly Man and to follow how these beautiful and majestic bears tear into an adult man and his girlfriend while they are still alive. What to make of bears now? Are bears in reality victims or coldblooded killers? Perhaps they are both possibilities at the same time and perhaps neither of them applies; but the fact is that each of the films shows only a segment, only a part of the reality that is interesting for the momentarily evoked story.

Michael Renov writes that "all discursive forms - documentary included - are, if not fictional, at least fictive" (Renov, 1993, p. 7). Noël Carroll has reservations about similar statements. He states that events in a documentary film nevertheless did play out in the living world without regard to a story. He considers causal relations, which according to our statements are subject to a story, as truthful. As an argument he presents one work from the series Wings of the Luftwaffe. In it the authors accentuate the great importance of German aviation, which in their opinion enabled the development of the gigantic American airplanes used on D-Day for dropping parachute units (and thus also influenced to a great measure modern aviation): "Now, if we suppose that the makers of Wings of the Luftwaffe are correct in identifying the significance of German glider research as a forerunner of, as well as 
a contribution to, the evolution of contemporary military aircraft, then the relation between the glider research and the present is hardly occult or fictional" (Carroll, 1996, p. 289).

In reality this is more complicated, however. It's enough to ask the question: how could German aviation influence American aviation? Perhaps German aviation came to the American, knocked on its door, told it what it ought to do and American aviation applied this in its own airplanes, waved a magic wand and the airplanes were in the world?

German aviation, like American aviation, is an abstract concept which hides within it many specific phenomena: from researchers through spies and pilots to cooks, mechanics and technicians, and from airplanes through calculations to pencils. This is the very problem with concepts that leads Hayden White to attribute a tropological character to history. In White's opinion historical narrative is on principle founded on one of the known genres (such as romance, tragedy, comedy or satire). What's important is that each narrative is connected with different speech tropes and figures (metaphors, metonymy, synecdoche and irony). Authors use narrative structures and speech resources so that they can make comprehensible units for the reader (see Carroll, 1996, p. 1-11; White, 2011, p. 26-61).

In this case this is metonymy, which inhibits us if we say that German aviation preceded that of America: "With metonymy we perceive phenomena implicitly as the bearer of a mutual relationship of individual parts; on its basis we can achieve reduction [emphasis by Hayden White] of one of the parts for only aspect or functional part of another" (White, 2011, p. 57). Thunder peals out. German research is in advance of that of America. Except that the existence of German research itself could not influence American aviation without specific events. Without there being some specific people who got access to some specific material that these specific people applied to a specific problem. Suddenly we have got ourselves into a situation where we can construct a fully new story, for example, about the role of American espionage, which infiltrated German research and obtained secret records which American scientists could use with the construction of their airplanes. We can thus state: without American espionage the airplanes which dropped parachutists over Normandy on D-Day would have never originated.

Who is right, then? We or the creators of Wings of the Luftwaffe? Or someone else who would rather talk about the difficulties faced by American scientists who had to decipher the secret materials, only thanks to which they could develop these airplanes. Without American scientists the airplanes that dropped parachutists on the French coast would never have been built. Or will someone else be right, when they invoke: thanks to the fact that 13 billion years ago the big bang took place and space originated, and aside from other things, 
the airplanes originated which dropped parachutists during the American offensive. Let's say that everyone equally has the (un)truth. Everyone states an equal, partial historical truth which reflects only a segment of reality relating to the selected story.

Because it is not true that German aviation research enabled the origin of American airplanes if we do not point out the role played by American espionage, the role also played by American scientists and the role played by the endless number of other details which we overlook because we have no awareness of them, let alone recordings. Relationships that we consider as causal thus upon closer look crumble into a thick network of smaller and smaller lines, connecting different mutual associated and unassociated events but which can also be divided, just as the relations between them, ad infinitum - as needed.

In short, no atomic historical fact exists, and historical truth is always partial. The truth which we can articulate about events in the real world says that two and two is five, because we did not observe and did not record the number one. But two and two without a one is not five and never will be. Therefore, a documentary film in relation to living reality is doomed to incompleteness. It is not capable of capturing even the reconstruction of an event itself and is thus made up of a selection of clues in a story that links apparent or partial truthful relations. We see that an attempt to define a documentary film with the help of its relationship to the real world fails. The film medium in short is unable to say how this was in reality.

\section{Works cited:}

Carroll N. 1996. "Nonfiction Film and Postmodernist Skepticism." In: Bordwell, D. and N. Carroll (eds.). Post-theory: Reconstructing film studies. Wisconsin: The University of Wisconsin Press, pp. 283-306.

Ferenčuhová, M. 2009. Odložený čas. Bratislava: Slovenský filmový ústav, Vysoká škola múzických umení.

Nichols B. 2011. Úvod do dokumentárního filmu. Praha: Akademie múzických umění.

Renov M. 1993. Theorizing Documentary. London: Routledge.

Veyne P. 2010. Jak se píšou dějiny. Červený Kostelec: Pavel Mervart.

White H. 2011. Metahistorie. Brno: Host.

Marek Urban

Slovak Academy of Sciences, Institute of Theatre and Film Research

Dubravska cesta 9

84511 Bratislava, Slovak Republic

marek.m.urban@gmail.com

\section{Acknowledgement}

This work was supported by the Slovak Research and Development Agency under contract No. APVV-0797-12. 